MedieKultur | Journal of media and communication research | ISSN 1901-9726

Article - Theme section

\title{
'Barbarous cruelty at the British Museum': mediatization, authority, and reputation in nineteenth-century England
}

\section{Allison Cavanagh}

MedieKultur 2013, 54, 87-103

Published by SMID | Society of Media researchers In Denmark | www.smid.dk The online version of this text can be found open access at www.mediekultur.dk

This article considers the usefulness of mediatization theories in historical studies of the media. Using a series of letters published in the UK newspaper The Times between 1885 and 1886 as an example, the article examines the way in which processes of mediatization developed alongside the institutions of social and cultural power by which they were reflexively constituted. On the basis of Hjarvard's distinction between direct and indirect forms of mediatization, the paper looks at the ways in which the enunciation of moral authority and personal reputation were transformed by their incorporation into mediatized culture. At the same time, it is argued that mediatization is not a standalone process but is, rather, part of a wider set of social processes. The article reflects on the contribution of mediatization theories to developing a rounded picture of media history.

'What is reported of men, whether it be true or false, may play as large a part in their lives, and above all in their destiny, as the things they do' - Victor Hugo

\section{Introduction}

On the 21st of December 1885, The Times published a letter from a Mr William Brightwell, formerly a gardener at the British Museum, who wrote to complain that he had been dismissed from his job and called upon The Times for redress. This was the start of an affair, con- 
ducted almost entirely through the letters pages of 'The Thunderer', that reveals much about the changing cultural status of the press in the late nineteenth century and about the ways in which the media became "society's most important storyteller about society itself" (Hjarvard, cited in Livingstone, 2008, p. 5). This case, I argue, reveals aspects of early mediatization, the process "by which activities of various social spheres come to be conducted under the influence of the media, or by the logic of the media" (Rothenbuhler, 2009, p. 279). It refers to the ways in which both media and other institutions come to be governed by the "logic [...] the institutional and technological modus operandi of the media" (Hjarvard, 2009, p. 160). Mediatization involves the transfer of sets of practices, norms, and self-constructs (Thompson, 1995) from the media sphere to other areas of social life. Media become 'go-between' institutions, arbitrating and translating between other areas of social, cultural, and economic life. The story of William Brightwell, I argue here, is the story of one crucial juncture in the emergence of the mediatized society, the point at which moral regulation moved from traditional institutions of the church, the courts, and the family to become a mainstay for the incursion of the media and media 'logic' into the private sphere. It is a story that points to the conditions of emergence of the mediatized society in the new age of publicity that characterized the latter part of Queen Victoria's reign. It is also a story that brings together personal valour, "manly appeals," pigeon poisoners, and "right thinking Englishmen." It involved at one point or another the Head Librarian of the British Museum, Her Majesty's Office of Works, by association (in the mind of one reader at least) Richard Cross, the Marquis of Salisbury, Gordon of Khartoum, and a mild-mannered seven-year-old Times reader called Master George. To say nothing of the Museum Pigeons. The story begins, however, a little earlier.

The tale of William Brightwell began on the $21^{\text {st }}$ of November when an anonymous correspondent wrote to The Times to complain of an act of atrocious cruelty, the poisoning of pigeons at the British Museum. 'A Reader in the British Museum' alleged that he or she had witnessed the Clerk of Works spreading a "fiendish mixture" of poison for the pigeons to eat. A lurid description of the pigeons' agony ensued, concluding with a call to the public to give voice to its "resentment at this act of wanton barbarity" and to the RSPCA to intervene to prosecute ('A Reader in the British Museum', 1885, p. 7). The letter, although impassioned, was not qualitatively different than others that The Times published on similar themes. However, in this case, the author hit a nerve by designating the Clerk of Works himself as the perpetrator of the act, and the Clerk of Works, Pulman, responded by denying the offence and asking the writer to produce evidence (Pulman, 1885, p. 6). This was apparently provided, with the $11^{\text {th }}$ of December bringing reportage in the Police columns of the trial of Pulman and an editorial on the judgment of Sir James Ingham in the case. Ingham, on the expert testimony of the president of the Royal College of Veterinary Surgeons, had found that the "mischief" was in fact done by a witness in the case, Brightwell. The Times grumbled to a conclusion that the affair was clearly one of the British Museum's poor supervision of its employees, so that they "blundered into the commission of gross cruelty": 
To many who are entirely free from morbid sentimentality, the whole proceeding will appear extremely blameworthy; and if, as seems probable, we must regard MR PULMAN as a comparatively innocent instrument, it is impossible to feel that his superiors come quite well out of the transaction. (The Times, 1885a, p.9)

With this snippy rebuke, The Times clearly considered the matter closed. The case, however, was far from over. On the $21^{\text {st }}$ of December, Brightwell's first letter is published and "correspondence ensues."

Brightwell claimed that he has been dismissed from service for his testimony to the court against his employer. Citing his long service as a further extenuation, he argues:

I do think it very bad that after such long service, I should be dismissed at a moment's warning without anything against my character, and only because I was compelled to be the principal witness in the case at Bow-Street. I have done my duty faithfully and truthfully, and I trust I shall not be made to suffer as Mr. Pullman (sic.) wants (Brightwell, 1885, p. 7).

The following day sees the publication of two responses, published together under the title Cruelty to Pigeons at the British Museum, from Major-General Frederic Brine and 'A Library Ticket-Holder'. Both pieces are supportive of Brightwell and express outrage at his ill-treatment. The $30^{\text {th }}$ of December brings an anxious letter from 'A Lover of Humanity' calling for an update on the case in the name of "every right-thinking Englishman" (1885b, p. 6).

The Times, thus provoked, gives a thorough recap of the case and throws down an editorial gauntlet, calling for authorities to "furnish the explanation which, as most people will think, has already been too long withheld." Although The Times remains firmly on the fence as to responsibility in the case, "The character of a public servant, and by implication that of a public institution, are at stake and must be vindicated at whatever costs to the private prospects of an individual" (1885c, p. 7).

The Chief Librarian Edward Bond responded on the $31^{\text {st }}$ of December with a magisterial passing of the buck to the Office of Works, merely stating that Brightwell was indeed an employee of the Office of Works, which was indeed responsible for his work (1885, p.8). In the face of this, A.B. Mitford of the Office of Works also quickly sought to set the record straight, explaining that the "Board" had reviewed Brightwell's dismissal, finding it inopportune but not unjustified (1886, p. 6). "I think," he continues in a masterly piece of bureaucratic castling, "I am not violating confidence by saying that Mr. Bond concurs with the Board in this opinion." Checkmate.

William White (1886, p.8), however, smelled a rat. He had previously hesitated "to rush in where better men remain, and have too long remained, silent or indifferent" and was also quite certain that the previous correspondent had "no intention to deceive the public." Now though, he cannot help but assert that "Sir, there is more in the question than the public imagine," for the "Board": 
is a phantom of his official imagination [...] the Commissioners [...] are the Marquis of Salisbury, Sir R.A. Cross, Mr. Stanhope and Mr. Plunket [...] Did Mr. Mitford summon the two principal Secretaries of State and the President of the Board of Trade, or did he simply consult Mr. Plunket, and is the last-named gentleman the "Board" referred to?

With the waters of responsibility thoroughly muddied, re-enter Brightwell, now threshing piteously in bureaucracy's coils:

Sir, - most humbly and gratefully I beg to thank you for your kindness in laying my case before the public. I would not venture to ask any further favour if I could help myself out of my trouble, which I cannot do [...] I have inquired of all possible officials and been handed about from pillar to post.

Although the public had been informed that work had been found for him, Brightwell had seen no evidence of it. Moreover, Mr. Mitford:

throws a slur on my character [...] You, Sir, challenged Mr. Pulman to state anything against me, but he has not done it; [...] I am forced to clear myself as best I can by solemnly saying that no charge was ever brought against me, and no complaint ever made [...] except a trifling matter; I was reported for calling a little boy who came to play in the grounds "Georgie" instead of "Master George". (1886a, p.8)

The invocation of Georgie, however, proves to be an error. Readers of The Times on the $9^{\text {th }}$ of January 1886 may have shared the surprise of one reader who:

woke up this morning with a headache; and papa says it is because I find myself famous. He has just read to me a letter from the man who was the gardener here [...] I do not think that the gardener has told all the story.

'Master George' relates the story of his own attempts to prevent Brightwell from first "knocking over" pigeons and later trapping them. This, continues Georgie:

is my first letter to a newspaper. Papa calls it a 'Contribution to the Great Pigeon Row' and he tells me it is proper to write this in capital letters. And I hope, dear Mr. Times, that you will find a space for it in your valuable columns (I am told this is the right way to ask), and I shall always be glad to write to you on important subjects. $(1886$, p. 7$)$

The last word, however, goes to Brightwell. On the $12^{\text {th }}$ of January, he writes to inform The Times that he has regained his job and to thank all concerned. However, he cannot resist one last barb. '“Master George,' or Master George's father says he would like to knock me down because I snared the pigeons [...] I was compelled to do that by Mr. Bond and the clerk of the works" (1886b, p. 6).

The case of Brightwell gives us an insight into processes of mediatisation in the UK. Media historians would look to the birth of the mass popular press in the closing years of the nineteenth century as the point at which mediatisation picked up pace. The launch of 
the halfpenny newspaper, a model cast by Harmsworth's Daily Mail in 1896, ushered in an era of mass journalism. This was an era in which journalism came to speak to and for the masses, in which the newspaper came to be rooted in daily experience. It was also one in which the delimited boundaries of the press began to give way. The decline of the working class and radical press by the 1850s (Conboy, 2004), the formal independence of the press from political patronage and the concomitant freedom to assume the status of a political actor (Chalaby, 1998; Lee, 1976), the increasing internationalization of journalism (Weiner, 2011), and the rise of a new journalistic aesthetic sited at the juncture between entertainment and factuality all combined to draw the press from its usual haunts - the clubs, salons, and drawing rooms of the powerful - and out onto the streets.

Sometimes, however, the streets came to the press, and the case of Brightwell is one such example. I will here consider it as a study in an emergent sensibility, as an exception that proves the rule of the newly developed media codes, roles, and practices. The development of rules is a particularly important area to examine. As Lundby has argued, "social form is constituted through continuous patterns of social interaction. Media logic is a codification of how media formats work; of rules, ways and regulations in 'the underlying interactive order"' (Lundby, 2009, p. 110). It is also crucial as it gives us a means of empirically grounding analyses of mediatization. As Hjarvard has rightly argued:

\footnotetext{
Mediatization theory not only needs to be well-specified, comprehensive and coherent, but it must also prove its usefulness as an analytical tool and its empirical validity through concrete studies [...] (it) has to be able describe overall developmental trends in society across different contexts and, by means of concrete analysis, demonstrate the impacts of the media on various institutions and spheres of human activity. (Hjarvard, 2008, p. 113)
}

This points to the necessity for mediatization theory to connect the general with the specific, and this is never more important than in the field of media history. Studies of mediatization are, of course, inherently historical in the first place. "By mediatization," argues Krotz, "we mean the historical developments that took and take place as a result of change in (communication) media and the consequences of those changes" (2008, cited in Livingstone, 2008, p.5). "The very idea of mediatization arises in historical thinking" (Rothenbuhler, 2009, p. 280). If historical perspectives have much to offer mediatization theory, it is also true that mediatization as a concept has much to offer historical studies of the media and media-dense societies. The study of media history has developed entrenched problematics surrounding the history of specific institutions (for instance, the BBC in the UK) and the division of media into specific mediums (see Schudson, 1991). As a consequence, the field has become highly specialized yet often remote from social and cultural histories and inimical to theory.

However, as Rothenbuhler notes, historical studies of mediatization have also suffered from a number of limitations. In the first instance, due to the prominence of medium theory as a point of entry into the area, technological determinism and agency have become 
dominant issues. The field has also been governed by two major concerns: media and the phenomenology of perception, drawing on the work of McLuhan (1962), Eisenstein (1980), Thompson (1995), and Innis (1951) as well as the mediatization of politics. Whilst these areas are well developed, there is little scholarship to connect these radically divergent concerns. Studies have furthermore characteristically taken a long-term approach, viewing developments over an extended period (e.g. Thompson, 1995; Meyrowitz, 1985), a canvas on which only the broadest brushstrokes of change - the rise of the nation state, the scientific revolution, the transformation of publicness - are discernible. So, whilst a macro focus contextualizes and identifies trends, it needs to be complemented by smaller-scale studies focusing on repeated interactions that create the path dependencies at the root of change.

There is thus a need to examine other areas of social life on a smaller scale in accounting for mediatization. The case of Brightwell allows consideration of two of these, firstly, the nature of identity construction and mediatization and secondly, the link between mediatization and social structural change. Below, I will use as an organizing rubric the distinction between direct and indirect mediatization proposed by Hjarvard (2008). Direct mediatization refers to cases in which an activity previously conducted in one arena comes to be conducted through or is strongly influenced by media logics. The best example of this is the political arena, although the organization of youth cultures (Livingstone, 2008) and religion (Hoover, 2009) are other good cases in point.

The gradual movement of moral regulation from the courts and the church to the media in the wake of secularization and rapid social transformation - in this case the largescale transfer of power from the old order of the landed patrician class to the new bourgeois - is another such example of direct mediatization. Greater democratization of the press and its concomitants, the fall of the political press, and the rise of sensationalism support the extension of mediatization into the private sphere, opening up the inner world of the family, home, and identity to a media logic that was already transforming political and commercial life. To capture this process at its inception, I will look at the ways in which the press styled itself as a moral intermediary and claimed a role in this sphere.

However, it is not enough to focus only on the media, for to do so would be to take for granted what we seek to explain, namely how the media came to be legitimated in this field. I will also examine the ways in which consent and consensus surrounding the validity of the press were generated through consideration of the ways that others - both the parties involved in the case and a wider readership - also sought to legitimize their own positions as commentators. I argue that the press' credibility is 'talked into being' as part of a wider expansion of social control.

The second key issue is that of identity construction. I refer here to the idea of indirect mediatization. Indirect mediatization refers to cases in which an activity is "increasingly influenced with respect to form, content, or organization by mediagenic symbols or mechanisms" (Hjarvard, 2008, p. 115). In the case of Brightwell, I look at how the different 
parties used a mediagenic repertoire to establish their interventions. This, I argue, points to the fact that mediatization was already highly developed in the nineteenth century, at an earlier stage than many would credit.

\section{Mediatization and cultural authority}

Let us begin, then, with the idea of 'direct' mediatization (see above). Altheide and Snow have argued that areas of social life become subject to the media, adopting "a media logic and specific media formats as their own institutional strategies," and as a result, they "become part of the total media culture" (1979, p. 16). They see mediatization as the incorporation of a media logic by other institutions, one in which the form of media takes over from the content. What I wish to argue here is that this process is less directed than Altheide and Snow envisage. Rather than the media influencing social practices and institutions with preformed logics of their own, media and other social actants co-develop and are mutually constitutive. In order to illustrate this process, I consider the ways in which authority and social legitimacy are developed in the series of exchanges under review. I will consider two points, firstly who in these debates has a legitimate right to speak and how this is established and secondly, how the press establishes its own credibility.

Those not directly involved in the case needed to offer some warrant and means of establishing their own identities as legitimate interlocutors, rhetorical or otherwise. This was necessary not merely to provide a rationale for publication but also to entitle their views to serious consideration. The primary way in which the letter writers to The Times establish their own right to speak is through the invocation of personal attributes. MajorGeneral Frederic Brine, for example, invokes his own credentials through name dropping. Thus, "I had to go to the British museum with the librarian of this club (the Athenaeum, which he gives as his address) about the decoration issued by Gordon at Khartoum" and "I went to the Royal Humane's Society's office, and, thanks to General Nicholson, R.E., satisfied myself that he (Brightwell) had saved three lives" (1885, p.7). His warrant for investigating Brightwell's "standing" and then publicizing the results of his sleuthing is his own status as an insider, a fixture of London 'Society'.

Others must use more prosaic warrants. William White uses his profession to authorize his intervention by giving his address at the Royal Institute of British Architects and by ostensibly restricting his statements to matters falling within his purview as an architect.

\footnotetext{
Sir, [...] if (the question) were not one which touches the public buildings of this country even more cruelly than it appears to have affected the museum pigeons. I would not thus rush in where better men remain, and have too long remained, silent or indifferent. (1886, p. 7)
}

Other pseudonymous writers fall back on their status as library users, with 'A Ticket Holder' (1885, p. 7) and 'A Reader in the British Museum' (1885, p. 7) simultaneously establishing their social capital as members of the library and invoking a consumer identity. The dual 
member/consumer identity gives the writers a position from which to make legitimate demands as individuals (see Trentmann and Taylor, 2006). A counter position, and one more in keeping with The Times' own public persona, is taken by 'A Lover of Humanity' (1885b, p. 6), who speaks on behalf of "every right-thinking Englishman," identifying his/ her call for explanation with the public interest. The Times takes up this intervention and amplifies it in its editorial of the same day. Master George (or perhaps his father) disguises a "right of reply" as a whimsical intervention, drawing upon an affectation of childhood innocence from his opening salutation - "Dear Mr. Times" - to his invocation of the appropriate rules of correspondence (see above).

A second way in which participants establish their right to speak is through an orientation toward media narratives, in this case that of the 'media crusade'. This was quite a novelty in the 1880s. Most historians credit William Stead, editor of the Pall Mall Gazette, as being the first to make crusades a key platform in the UK. Between 1883 and 1885, Stead ran a series of media crusades on issues including poverty (The Bitter Cry of Outcast London, 1883), the provisioning of the Navy, the General Gordon affair, and the infamous Maiden Tribute of Modern Babylon crusade against child prostitution (see Chalaby, 1998, Weiner, 2011). Features of crusading journalism - such as the use of inflated and emotive language, the personification of issues and reduction of them to individuals, the unfolding of a narrative over a succession of publications, and appeals to specific or generalized authority figures for action - were all already in circulation by 1885 , albeit as a newly minted coin.

The writers to The Times use similar conventions. The public's right to know "what are the Museum authorities and the authorities of the Board of Works about that they do not clear themselves from the charge of culpable inertion and favouritism" ('A Lover of Humanity', 1885b, p.6); the personification into personal attributes, for example, Brightwell's good character as a former hero in Brine's account or 'A Lover of Humanity's' invocation of his 'manly appeal'; the use of overblown language ("Sir, there is more in the question than the public imagine..." (White, 1886, p. 5)) and description ("surely lingered in torment [...] and some are perhaps so lingering even now" ('A Reader in the British Museum', 1885, p. 7)); the consistent calls for action ("Will not the London public..." (ibid, p. 7), "Surely the trustees..." (Brine, 1885, p. 7), and "Cannot the society for the Prevention of Cruelty to Animals..." ('A Reader in the British Museum', 1885, p. 7)); and most importantly, the invocation of the public interest ("Thousands of your readers will be filled with indignation" ('A Library Ticket Holder' 1885, p. 7), "I am quite sure that Mr. Mitford has no intention to deceive the public..." (White, 1886, p. 5), and "Every right-thinking Englishman" ('A Lover of Humanity', 1885b, p. 6)) all invoke the emerging conventions of the crusade.

The Times itself draws on a rather different repertoire of symbolic resources in demonstrating its rightful intermediary role here. Although the paper, as the political paper of record, the first and most influential of the national newspapers, had an unquestioned authority status in political affairs, it entered uncomfortable territory when intervening in what was, essentially, a private concern. We can witness this disquiet in the tone of edi- 
torials and the ongoing attempts to hedge the paper's bets and distance itself from the discreditable Brightwell. Thus, "It is not without reluctance that we recur to (the case)...", and "Brightwell will be adjudged to be a silly fellow who does not know when to let well, or ill enough alone" (1885c, p. 7). A private dispute between a worker and his patrician employer is in some ways the stuff of nightmares for The Times. Even towards the end of the nineteenth century, there remained a lingering distrust of journalists within elite society. Journalism was not quite a respectable profession, and editors were not wholly to be trusted (Lee, 1976, p. 106). To 'call out' authority in this way was to risk emphasizing the fragility of the class détente that existed between the still largely aristocratic ruling class and the essentially middle-class press.

The Times positions itself in the first instance as an adjudicator, for example, in the editorial coverage of the hearing (see above). In this, The Times acknowledges the court's authority to pronounce on the guilt of the accused and to inflict punishment but claims for itself the right to determine the moral message of the case in the name of what "the public is entitled to expect" (1885a, p. 9). The court's proper domain is thus circumscribed in administrative terms, in contrast to The Times' own moral platform.

The sense of The Times as a moral court is further elaborated upon in the clear understanding by almost all of the participants that The Times has a legitimate claim to 'call out' authority. The editor himself expresses this:

MR. Pulman owes it to himself and the public to show that this imputation is unfounded. We shall be pleased to give him the opportunity of so doing; but if he declines, it will be necessary to make a further appeal to his official superiors [...] "e feel compelled to call upon MR. PULMAN to furnish the explanation which, as most people will think, has already been too long withheld. (1885c, p. 7)

The legitimacy of The Times right to intervene is acknowledged by all parties to the dispute, for example Mitford ("Your leading article of yesterday [...] renders it necessary for me to state..." (1885, p. 6)) and Brightwell ("You, Sir, challenged Mr. Pulman to state anything against me, but he has not done it..." (1886a, p. 8)). This is so much the case that spectators are led to infer guilt from any instances of untimely reply, such as "I have looked through your columns day after day to see what response would be made" ('A Lover of Humanity',1885b, p. 6 ). The Times bolsters its claims to moral authority by invoking the mechanisms of the court- impartiality ("BRIGHTWELL will deserve no sympathy, and get none, if Mr. PULMAN is in the right; but he will deserve a great deal if MR. PULMAN is in the wrong"); the right to call witnesses ("If he declines, it will be necessary to make a further appeal to his official superiors..."); the imputation of consequences ("Indeed in the latter case, the matter would probably not end in mere platonic sympathy for the victim") (1885c, p. 7); and adherence to particular standards of factuality and proof, albeit social rather than juridical in nature (see below). 
The Times' authority and credibility as a participant is derived from its well-established status as the spokesman for elite public opinion, and the paper, of course, is quick to make use of this. Thus, Brightwell "has appealed to public opinion, as in the circumstances he had every right to do, and he must abide by its verdict" (1885c, p. 7). Public opinion is, then, styled as the highest authority, a levelling force to which all must submit, from the highest museum authorities to the lowliest gardener - although, of course, it is also a force that is uniquely directed and controlled by the press.

The symbolic and rhetorical resources used here by both the press and the readers serve to talk into being a credible intermediary in public affairs in the form of the press. The referencing of rules, most explicitly in the case of 'Master George'; the use of common narrative forms; the expectation of a right of reply by both Brightwell and 'Master George'; the invocation by all parties of a public right to know and to investigate; and the clear understanding of the legitimacy of an editor's demand for information serve to authenticate and inscribe the press as a legitimate moral force. However, in talking the press's authority into being, The Times' letter writers style themselves as part of the same group, that category of people with a valid claim to express their opinions and have those opinions heard. The appeal to a public right to know both uses the notion of a public as a resource and constructs it as a particular group of people. The press and the public are of the same social class through the possession of shared 'habitus' in Bourdieu's terms, one centred on knowledge of the correct use of the media and of information. Of course, we know of the change that was on the horizon. The mass production of news brought about a profound shift in the relationship between editors and the public, from that of supposed intellectual equality to one often either of didacticism or moral entrepreneurship as the audience for newspapers expanded beyond the confines of the cognoscenti (Hampton, 2001). At this time, however, the public and its spokesmen were in the process of constituting one another.

Rather than involving the unfolding of the logic of the media onto other social institutions, this points to mediatization as part of a wider social transformation. The movement of moral decision making from the private to the public sphere reinforced an ongoing transfer of cultural authority to the new urban bourgeois. The middle class was defined by its media literacy and information 'savvy', just as the press was defined as its legitimate public face. The processes of mediatization and stratification were mutually elaborative and reflexively constituted.

\section{The mediatization of reputation}

As Hjarvard argues, it is often more difficult to pin down indirect forms of mediatization. Although direct mediatization involves a substitution, indirect mediatization has a more pervasive character, often taking the form of a 'general increase in social institutions' reliance on communication resources" (Hjarvard, 2008, p. 115). The difficulty of detecting indirect mediatization in an historical context, especially as it applies to the experience 
of mediatization before the twentieth century, is further compounded by the fact that the analyst is dependent on sources that are fragmentary, scattered, incomplete, and at best suggestive. These are also sources with which media professionals and scholars are less familiar, inevitably being personal reflections and testimony that appear most often as a blow-by-blow account of the record of another type of event or experience (Schudson, 1991, p. 180).

What I wish to consider here is how the Brightwell case sheds light on the enactment of personal identity on a media stage as an example of the kind of indirect mediatization that occurred in the nineteenth century. I argued above that a license to speak in public was achieved by referring to the explicit codes of media professionalism and specific enactments of 'public opinion' that were in the process of coming into being. Here, I would like to consider the ways in which public and private identity interact, particularly the ways in which Brightwell, as the 'petitioner' in this case, establishes his credibility as a participant.

Establishing a credible public persona is of paramount importance here. For Brightwell, writing to The Times, is not, as the paper contends, submission to impartial public opinion but is an exercise in overcoming a pre-existing discourse of suspicion against him. As The Times itself puts it:

We are quite ready [...] to suspend our judgment for a little longer and to acknowledge that, until the contrary is proved, MR. PULMAN should be presumed to have acted with justice and discretion. As a general rule such would undoubtedly have been the presumption. (1885c, p. 7)

Pulman, as Clerk of Works and Brightwell's superior, is presumed in the right in the absence of evidence to the contrary. "The character of a public servant, and by implication that of a public institution, are at stake, and must be vindicated at whatever costs to the private prospects of an individual" (1885c, p. 7). Indeed, it is only "the unfortunate contrast between his original letter to ourselves and the facts established in the police court" that lead The Times to entertain any doubt at all. The paper is driven by a fear of allowing Brightwell to "grandstand" in its pages ("He is thought by many - not without considerable reason [...] to be a martyr [...] We have no wish to encourage false martyrdom" (1885c, p. 7)), and The Times is keen to exonerate officials from blame.

Brightwell's chief, and indeed only, symbolic recourse in offsetting this disadvantage is to emphasize his respectable status. Respectability, for historians and sociologists alike, is seen as "a central mechanism through which the concept of class emerged" (Skeggs, 1997, p. 2). It was and is "a marker and a burden of class" (ibid. p. 3). For contemporaries, the distinction between the respectable poor and the dark underclasses of Victorian Britain was key to reconciling the demands of laissez-faire capitalism and an espoused Christian morality. For the poor themselves, respectability was the key both to unlocking the door of organized charity and accessing local and communal support networks (Ross, 1985). Respectability, however, was a double-edged sword. As Skeggs has argued in a different 
context, "respectability is usually the concern of those who are not seen to have it" (Skeggs, 1997, p. 1), and this was never more true than in the case of Brightwell. In taking his former employer to task in the public forum of The Times, Brightwell is obliged to appeal not to a jury of his own peers but to those of his employer, an effort that requires some finesse. His opening gambit is an invocation of a form of noblesse oblige that can only have warmed the hearts of the readers of The Times: "I have done my duty faithfully and truthfully, and I trust I shall not be made to suffer" (1885a, p. 8).

While other readers may demand and require actions and clarifications, Brightwell is left simply to "trust." The invocation of a master/servant relationship and the responsibilities that were held to attend each party certainly yields results. It is on the strength of this testimony that Brine, who becomes Brightwell's most formidable ally, acts. Brightwell, lacking Brine's social connections, is nevertheless able to access his social capital through the invocation of traditional relationships between servants and their social 'betters'. His next letter is of a similar nature, though emboldened by the presumption of common cause with The Times' editor. His employer, he says, has thrown "a slur on my character [...] You, Sir, challenged Mr. Pulman to state anything against me, but he has not done it; and as Mr. Mitford has not done it either, I am forced to clear myself as best I can" (1886, p. 8).

Clearing himself in this case is accomplished by invoking length of service, lack of precedent for the complaint, and his social standing in his own community: "The letter carriers all know me very well" (1886a, p. 8). This latter comments highlights his longstanding residency in the area (Little Russell Street), something to which only a respectable working man with a steady job could aspire. This area was noted in the 1880s for the large-scale conversion of 'grand' houses to multiple-occupancy lodgings. In his survey Maps Descriptive of London Poverty, 1898-9, Charles Booth lists Little Russell Street as a fairly comfortable area, comprising higher-class labourers and those with regular standard earnings (Englander \& O'Day, 1993). These indexes of respectability would have been readily understood by contemporaries.

It is also vital to Brightwell that Bond's description of him as a contractor's labourer is not allowed to stand:

It has been said that I was not a gardener at the British museum; this is incorrect. I am a gardener, and acted as such for 16 years [...] I was called a gardener at the Museum and nothing else; I did all the gardening work there that had to be done, and I did not do labourers' work (1886a, p. 8).

His insistence and repetition of this distinction points to its centrality to his case. As a gardener, he is of the respectable working class, a servant of a type more familiar to the aristocracy than are the rough labouring classes to which Bond absent-mindedly consigns him. The offence to which he confesses, calling a little boy by the affectionate name of 'Georgie', also fits with this image of the honest family retainer that Brightwell develops. Finally, Brightwell, in victory, is at pains to underscore the value of a symbolic victory even 
though his own victory is of a more material nature, the restoration of his job. "I have lost a month's wages, and shall lose besides 9s. $21 / 2$ d. in my weekly pay by this change; but I do not care for that, now that I have regained my character" (1886b, p. 6). By pointing to his own understanding of the greater value of reputation, along with the presumed corollary, an ability to put character over cash, Brightwell places himself firmly in the category of the respectable working class.

Brightwell's enactment of respectability is, then, one that specifically 'speaks to' the readership of The Times. It is a respectability founded in the country estate rather than in the factory or on the streets. Historians have long argued that the working poor developed and enacted multiple codes of respectability that existed alongside - sometimes supporting, sometimes conflicting with - middle-class ideologies of respectability. Peter Bailey has pointed to the ways in which respectability amongst the working classes "was practiced in a more limited and situational sense than that of a lived ideal or a permanent code of values, and [...] assumed as a role (or cluster of roles) as much as it was espoused as an ideology" (Bailey, 1979, p. 338). It was "always a process, a dialogue with oneself and with one's fellows, never a fixed position" (Peter Bailey cited in Ellen Ross, 1985, p. 41).

In this sense, "being respectable" was a practice assumed in specific situations, sometimes according to the lights of one's peers, at other times as a consciously assumed enactment of the respectable role proffered by others. As far as Brightwell is concerned, the latter case is clearly operative. The markers of respectability that he emphasizes are part and parcel of an elite's image of the respectable poor. Only by assuming the role of the humble retainer, symbolically laying his head in the lap of public opinion, can Brightwell hope to regain his lost respectability. In this sense, he enacts a mediagenic tableau-vivant of the wronged servant.

Underpinning this presentation, however, are a variety of symbolic and cultural resources. In order to do this, Brightwell brings together a variety of literacies- simple literacy, class literacy, and media literacy. He shows a clear and complex understanding of the nature of The Times as a public forum and later as a symbolic resource in his campaign. The choice of the letters page of The Times would, on the face of it, seem an odd one for a working man, and it clearly struck his contemporaries as unusual. The assumption that Brightwell had naively blundered into an arena in which he required a champion clearly motivates the chivalry of Brine and a 'Lover of Humanity', even while its tragi-comic elements prove distasteful to The Times' editor (see above). However, there is nothing in Brightwell's performance to suggest naive blundering. Indeed, as A.B. Mitford points out, Brightwell has been a skilful publicist:

Brightwell's conduct [...] had been such that it was not desirable to retain his services at the British Museum [...] The moment for dismissing Brightwell was singularly ill chosen [...] It would be difficult for anyone to believe that Mr. Pulman was not actuated by some feeling of resentment [...] His indiscretion has been Brightwell's good fortune for, had the latter been 
dismissed before the hearing of the case by the magistrate, this board would certainly not have induced the contractor to employ him in another place. (1886, p. 6)

This brings us back to the point I raised at the beginning of this section, namely the methodological problems involved in uncovering processes of mediatization. Historians' encounters with the processes of emerging mediatized cultures are nearly always retrospective accounts, usually of those who come to an awareness of media through their status as outsiders, and their accounts often read as confused attempts to recapture a process of perceptual transformation. In his study of working class autodidacts, for example, Rose cites J.R. Clynes:

Millions of men and women died in their towns and villages without ever having travelled five miles from the spot where they were born. To them the rest of the world was a shadowy place merging into the boundaries of unreality (cited in Rose 2001, p. 344).

For this group, Rose argues, the world beyond the narrow confines of the village was not merely irrelevant but literally incomprehensible, lacking any meaningful geography. This is confirmed by the radical Guy Aldred, for whom the world beyond the immediate confines of his experience was characterized by an "indefinable alienism":

The world to me was London [...] It was a wonderful world of magic and myth; and it seemed to me that in order to enter into relations with it, I would have to possess Aladdin's lamp (cited in Rose, 2001, p. 343).

Robert Roberts likewise notes that, lacking any connection to a greater polity, a "national morning newspaper had little appeal [...] London was a place where royalty lived, that and little more [...] They (the workers) did not feel the state as a reality at all" (cited in Rose, 2001, p. 344).

Rose also points to a corollary of this narrow outlook, namely that fictional characters and events assumed as great a reality in the minds of the isolated as did 'real' events and people.

The mediatization of an inner life is not, then, the overwriting of experience with new 'scripts' but its uncovering and reassignment to specific categories of social experience. For the isolated workers of the industrial north, all information mediated through print was conflated, assuming the same real or unreal character. The development of media literacy was a process of the transformation of reality.

However, as a member of the urban proletariat and as one who daily rubbed shoulders with the wealthier classes, Brightwell was no such outsider. If fact and fiction were blended together in the minds of the rural and factory proletariat of the north through ignorance, they are brought together intentionally in the case of Brightwell. His tableau of the wronged faithful servant convincingly weaves truths and fictions whilst steering the readers to his own conclusions. What this points to and confirms is that the process of indirect mediatization is key to enforcing social divisions within the working class, between the 
rural and urban proletariat, between those whose cultural and media literacy allow them to think in, access, and manipulate media symbols and those who have media symbols thrust upon them. Brightwell may suffer economic 'exclusion', but his ability to manipulate media symbols and narratives is a potent resource in the newly transformed cultural landscape of 1880s London.

\section{Conclusion}

The case of Brightwell catches the process of mediatization at a crucial point in its development. The formal and informal rules of the media are at this stage still developing, and we can see here the co-existence of multiple ways of relating to communications media. Krotz (2009) has differentiated between mediated and mediatized communication, and the movement between these is clearly evident in these letters. For Brine, the letters pages are an extension of his informal social circle, and this is clearly also the case for Bond, for whom being required to comment on the affairs of labourers in the pages of The Times is a rather baffling development. These readers represent a 'residual' sensibility in Raymond Williams' (1977) sense of the term, those for whom communication is merely mediated. The letters of Brightwell and 'A Reader in the British Museum' point toward an emergent sensibility and a changing role for the press. For Brightwell, the media is a personal platform: What is at stake is his reputation, his public persona. That he identifies his regained 'character' with exoneration in the pages of The Times points to the already present integration of media - even disregarding 'The Thunderer' - and everyday life. 'A Reader in the British Museum', however, gestures to the future. This letter, in its use of the emergent language of the moral crusade, the appeal to public sentiment rather than to public reason, and the invocation of the power of the press to bypass formal institutions, points to the role that the press would style for itself. These different levels of mediation and mediatization point to the ways in which a medium-specific logic (The Times as the paper of the 'Old Boys' Club') gives way to a wider 'media logic', a sense of how public presentations of issues and of selves 'work' in the press.

Mediatization, then, is not a new theory; it is a way of re-framing and reconceptualizing pre-existing research foci so as to allow us to move away from rather stale divisions, such as those between media on the one hand and society on the other. Media historiography has tended to see its work in terms of 'impacts' or 'influences', as of one self-contained body, institution, or discourse exerting force on another. However, mediatization as an approach allows us to move away from this and highlight how media logics and practices emerge alongside and as integral parts of the social. This is not a question, of course, of tracking the unfolding logic of the media but of the ways that mediatization is 'called' into being. In this case, morality becomes the domain of the press as a result of changes in the intensity of the relationship and interaction between media and the urban bourgeois class. Mediatization, in this guise as the twin processes of the mediatization of moral authority and the moralization of the media, thus emerges out of the contradictions between the expectations of 
different readerships, the irreconcilability of social roles and positions, and the social and political transformations sweeping nineteenth century Europe.

\section{References}

'A Library Ticket Holder' (1885, 22 December) Cruelty to Pigeons at the British Museum [Letter to the Editor] The Times p. 7.

'A Lover of Humanity' (1885a, 16 December) The Pigeons at the British Museum [Letter to the Editor] The Times p. 13.

'A Lover of Humanity' (1885b, 30 December) The Museum Pigeons [Letter to the Editor] The Times p. 6.

'A Reader in the British Museum' (1885, 21 November) Barbarous Cruelty [Letter to the Editor] The Times p.7.

Altheide, D., \& Snow, R. (1979). Media Logic. Beverly Hills: Sage.

Bailey, P. (1979). Will the real Bill Banks stand up? Towards a role analysis of mid-Victorian respectability Journal of Social History, 12, 336-353.

Bond, E. (1885, 31 December) The Museum Pigeons[Letter to the Editor] The Times p. 8.

Brightwell, W. (1885, 21 December) Cruelty to Pigeons at the British Museum[Letter to the Editor] The Times p. 7.

Brightwell, W (1886a, 8 January) The British Museum Pigeons[Letter to the Editor] The Times p. 8.

Brightwell, W. (1886b 12 January) The British Museum Pigeons[Letter to the Editor] The Times p. 6.

Brine, F. (1885, 22 December) Cruelty to Pigeons at the British Museum[Letter to the Editor] The Times p. 7. Chalaby, J. (1998). The Invention of Journalism Basingstoke: Macmillan.

Conboy, M. (2004). Journalism: A Critical History London: Sage.

Eisenstein, E. (1980). The Printing Press as an Agent of Change: Communications and Cultural Transformations in Early-Modern Europe Cambridge: Cambridge University Press.

Hampton, M. (2001). 'Understanding media': theories of the press in Britain, 1850-1914 Media, Culture and Society 23, 213-31.

Hepp, A. (2009), Differentiation: Mediatization and Cultural Change in K. Lundby (Ed.), Mediatization: concept, changes, consequences (pp. 139-157) New York, Oxford: Peter Lang.

Hjarvard, S. (2008). The Mediatization of Society: A theory of the media as agents of social and cultural change Nordicom Review 9, 105-134.

Hoover, S. (2009). Complexities: The case of religious cultures in K. Lundby (Ed.), Mediatization: concept, changes, consequences (pp. 123-138) New York, Oxford: Peter Lang.

Innis, H. (1951). The Bias of Communication Toronto: University of Toronto Press.

Krotz, F. (2009). Mediatization: A Concept with which to grasp media and societal change in K. Lundby (Ed), Mediatization: concept, changes, consequences (pp. 21-40). New York, Oxford: Peter Lang.

Lee, A. (1976) The Origins of the Popular Press 1855-1914 London: Croom Helm.

Livingstone, S. (2008). On the mediation of everything: ICA presidential address 2008. Journal of Communication, 59, 1-18.

Lundby, K. (2009). Media Logic: Looking for Social Interaction in K. Lundby (Ed.), Mediatization: concept, changes, consequences (pp. 101-119). New York, Oxford: Peter Lang.

'Master George' (1886, 9 January) The Pigeons at the British Museum [Letter to the Editor] The Times p. 7.

McLuhan, M. (1962). The Gutenberg galaxy: the making of typographic man Toronto, London: University of Toronto Press. 
Meyrowitz, J. (1985). No Sense of Place: The Impact of the Electronic Media on Social Behavior Oxford: Oxford University Press.

Mitford, A.B. (1886, 1 January) The Museum Pigeons [Letter to the Editor] The Times, p. 6.

O'Day, R and Englander, D (1993). Mr. Charles Booth's Inquiry: Life and Labour of the People in London Reconsidered London: Hambledon Press.

Pulman, C. (1885, 23 November) Barbarous Cruelty [Letter to the Editor] The Times p. 6.

Rothenbuhler, E. (2009). Continuities: Communicative Form and Institutionalization in K. Lundby (Ed.), Mediatization: concept, changes consequences (pp. 277-292). New York, Oxford: Peter Lang.

Rose, J. (2002). The Intellectual Life of the British Working Classes New Haven and London: Yale University Press.

Ross, E. (1985). 'Not the Sort that Would Sit on a Doorstep': Respectability in Pre-World War I London Neighbourhoods International Labour and Working Class History 27, 39-59.

Schudson, M. (1991). Historical Approaches to Communication Studies in K. Jensen \& N. Jankowski (Eds.), A Handbook of Qualitative Methodologies for Mass Communications Research (pp. 175-189). London: Routledge.

Skeggs, B. (1997). Formations of Class and Gender: Becoming Respectable London: Sage.

Thompson, J. (1995). The Media and Modernity: A Social Theory of the Media Oxford: Polity.

The Times (1885a, 11 December) Sir James Ingham was yesterday called upon to ...(Editorial) The Times p. 9.

The Times (1885b, 11 December) Police Column The Times p. 4.

The Times (1885c, 30 December) It is not without reluctance that we recur to...(Editorial) The Times p. 7.

Trentmann, F. \& Taylor, V. (2006). From Users to Consumers: Water Politics in Nineteenth Century London.

in F. Trentmann (Ed.), The Making of the Consumer: Knowledge, Power and Identity in the Modern World (pp. 53-79). Oxford: Berg.

Weiner, J. (2011). The Americanization of the British Press, 1830s-1914: Speed in the Age of Transatlantic Journalism Basingstoke: Palgrave Macmillan.

White, W (1886, 2 January) The Museum Pigeons [Letter to the Editor] The Times $p .7$.

Williams, R. (1977) Marxism and Literature Oxford, Oxford University Press.

\author{
Allison Cavanagh \\ Lecturer, PhD \\ Institute of Communications Studies \\ University of Leeds, United Kingdom \\ a.e.cavanagh@leeds.ac.uk
}

